\title{
Chronic progressive external ophthalmoplegia and pigmentary degeneration of the retina
}

\author{
P. V. MILLS, D. I. BOWEN, And D. S. THOMSON \\ From the Departments of Ophthalmology, Cardiff Royal Infirmary and Cheltenham General Hospital
}

The rare association of external ophthalmoplegia and ptosis with pigmentary degeneration of the retina was first described by Barnard and Scholz (1954) in a report of four cases. The subsequent literature was reviewed by Davidson ( 1960 ), who found that only eighteen cases had been described, and added one further case. Within this series he was able to define a relatively homogenous group of twelve cases. They manifested a syndrome characteristically occurring in females with the onset of ptosis in childhood and of external ophthalmoplegia in adolescence or early adult life. The pupils were normal and an atypical retinitis pigmentosa was present with normal retinal vessels and optic discs. The visual fields were variable showing either no defect, peripheral contraction, or the characteristic annular scotoma of retinitis pigmentosa.

The present communication reports two further cases of this rare syndrome and reviews the relevant literature subsequent to I960. Serum enzyme studies in eleven other patients with progressive external ophthalmoplegia unassociated with pigmentary degeneration of the retina are also reported and the findings discussed.

\section{Case reports}

Case I, a girl now aged 14 years, was first seen by one of us (D.S.T.) when aged 6 years. She was initially referred for an eye examination because she was observed to hold books close to her eyes. The uncorrected visual acuity was 6/9 in each eye and widespread pigmentary changes were noted in both fundi. The child was underweight and enuritic. The Wassermann reaction was negative. When aged Io she was noted to have a mild bilateral ptosis which was not improved by an injection of Tensilon, and a year later, because of her poor physical development, she was investigated as a possible case of Turner's syndrome, but chromosome studies ruled this out. By age i 3 the ptosis had increased markedly and bilateral symmetrical limitation of ocular movements, especially elevation, was observed, but no diplopia was elicited. At this stage she was also noted to be incoordinated and ataxic, falling frequently when tired.

She has one normal brother aged 9 years and the mother's fundi are normal. There is no known history of ptosis in the family.

EXAMINATION

She was co-operative and of fair intelligence but markedly undeveloped for her age in height, weight, and secondary sex characteristics (Fig. I). There was marked symmetrical bilateral ptosis with characteristic frontalis overaction (Fig. 2). The external ocular movements of both eyes were symmetrically limited and elevation was absent. The pupils were normal. The visual acuity of 
the right eye was $6 / 9$ with $+\mathrm{I} \mathrm{D}$ cyl., axis $168^{\circ}$, and of the left eye $6 / 12$ with $+0.5 \mathrm{D}$ cyl., axis $20^{\circ}$. Fundus examination showed clumping of the retinal pigment, which was coarse at the periphery but finer posteriorly, producing a dust-like appearance. The choroidal vascular pattern was visible (Fig. 3). The discs were normal and the retinal arterioles of normal calibre. The visual fields were full $(2 \mathrm{~mm}$. white target at $\mathrm{I} / 3$ metre).

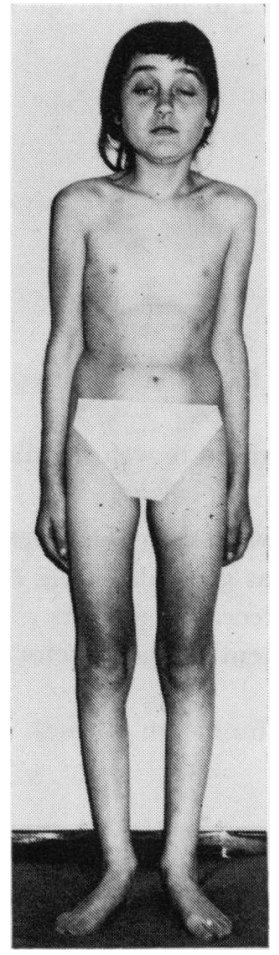

FIG. I Case I. Full frontal view to show retarded development

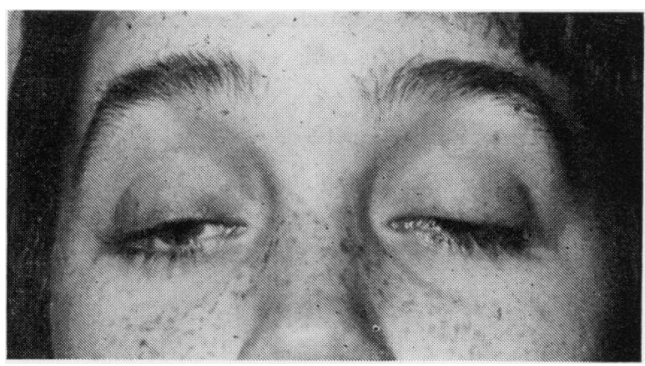

FIG. 2 Case I. Facial view to show ptosis

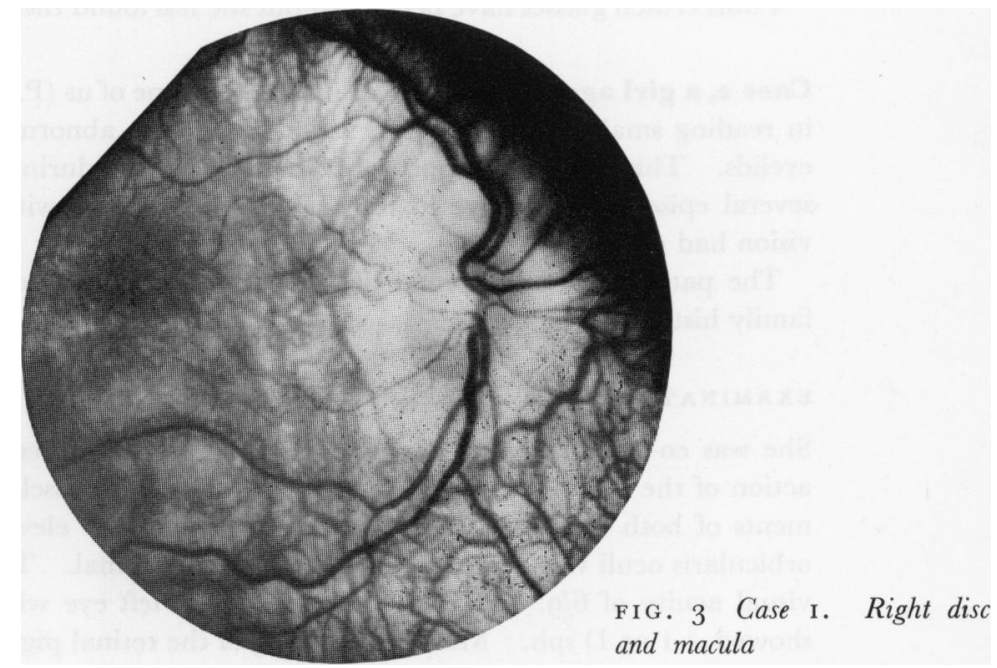

Speech and hearing were normal and examination of the cranial nerves revealed no abnormality. The general skeletal musculature was poorly developed and the muscle tone flaccid. In the upper limbs there was symmetrical muscle weakness, ataxia, dysdiadochokinesis, and a gross intention tremor. The lower limbs also showed poor muscle power and marked ataxia. She was unable to walk along a straight line and could not stand with feet together and eyes closed. The deep tendon reflexes were all present but diminished and the plantar responses were weak flexor. No sensory disturbance was detected.

\section{INVESTIGATIONS}

Blood: $\mathrm{Hb}$ and white blood cells normal; the blood film showed no acanthocytosis or other abnormality; serum aldolase $7 \mathrm{~S}-\mathrm{L}$ units $/ \mathrm{ml}$. (normal range $3^{-8}$ ); serum creatine phosphokinase $6 \cdot 0$ Sigma units (normal range o-12); electrophoresis showed no betalipoproteinaemia or other abnormality; Wassermann reaction negative; serum cholesterol $195 \mathrm{mg}$. per cent.; protein bound iodine $4.9 \mu \mathrm{g}$. per cent. 
Urine: No albumln or sugar present.

Radiology: Skull $x$ ray normal; skeletal maturation consistent with chronological age.

Buccal smear: 33 per cent. Barr bodies.

Cerebrospinal fluid: Clear and colourless, pressure normal; protein $130 \mathrm{mg} . / 100 \mathrm{ml}$; glucose I21 mg./1 oo ml.; chloride $40 \mathrm{mEq} / \mathrm{l}$; cells Io red blood cells/c.mm.

Tensilon and prostigmine: Tests negative.

Electroencephalogram: Partial right bundle branch block and a frontal plane QRS axis of minus $90^{\circ}$. Occasional extrasystoles (Dr. James Wilkinson).

PROGRESS

During the past 12 months the ataxia has increased and she now has difficulty in walking across a room. She spends most of her day in a wheelchair.

Ptosis crutch glasses have been tried but she has found them too painful to wear regularly.

Case 2, a girl aged 14 years, was first seen by one of us (P.V.M.) when she complained of difficulty in reading small writing, though the most obvious abnormality was gross drooping of both upper eyelids. This abnormal appearance had developed during the preceding 3 years. She had had several episodes of red eye in the same period treated with ointment by her doctor. No double vision had occurred.

The patient has one normal brother aged 7 and both parents' fundi are normal. There is no family history of eye disease.

\section{EXAMINATION}

She was co-operative and of normal intelligence. Marked bilateral ptosis was present with poor action of the levators and overaction of the frontalis muscles (Fig. 4). The external ocular movements of both eyes were limited in all directions and elevation was absent. No weakness of the orbicularis oculi was evident. The pupils were normal. The right eye was emmetropic and had a visual acuity of $6 / 9$. The visual acuity of the left eye without correction was $6 / 9$ and refraction showed $+\mathrm{r} \cdot 25 \mathrm{D}$ sph. Marked clumping of the retinal pigment was present over the whole of both fundi, the clumping being more coarse at the posterior poles and in the periphery than in the equatorial region (Fig. 5). The optic discs and retinal vessels were normal. The visual fields were full (I $\mathrm{mm}$. white target at $\mathrm{I} / 3$ metre).

A mild myopathic weakness was present with definite weakness of the flexors of the neck and her general skeletal musculature was thin. In the upper limbs there was ataxia, dysdiadochokinesis, and an intention tremor. The lower limbs were also ataxic and her gait was unsteady. Deep tendon reflexes were absent in the upper limbs while in the lower limbs they were brisk. The plantar responses were flexor. No sensory disturbance was detected.

\section{INVESTIGATIONS}

Blood: $\mathrm{Hb}$, white blood cells, blood film, erythrocyte sedimentation rate, serum sodium, potassium, urea, acid and alkaline phosphatase all normal; no serum phytanic acid detected; Wassermann reaction, Reiter protein complement-fixation test, and Kahn test negative; total serum protein $7 \cdot 1 \mathrm{~g}$./ $100 \mathrm{ml}$; ; serum albumin $4.8 \mathrm{~g}$./100 ml.; electrophoresis: slightly raised gamma globulın; serum creatinc phosphokinase II $\mathrm{mU} . / \mathrm{ml}$. (normal 5-30); serum glutamic-oxaluacetic transaminase 26 units $/ \mathrm{ml}$. (normal 5-35); serum aldolase $2 \cdot 2 \mathrm{mU} . / \mathrm{ml}$. (normal $0 \cdot 9-2 \cdot 5$ ). 
(4)

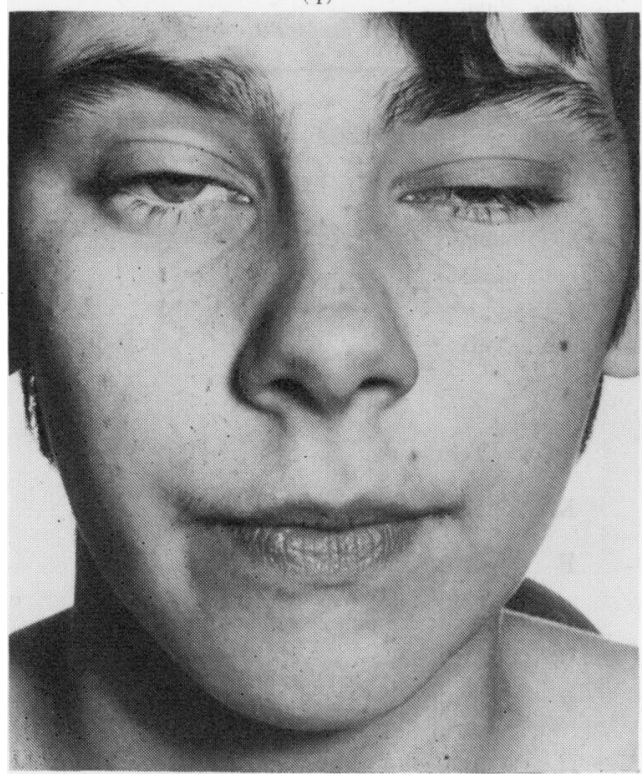

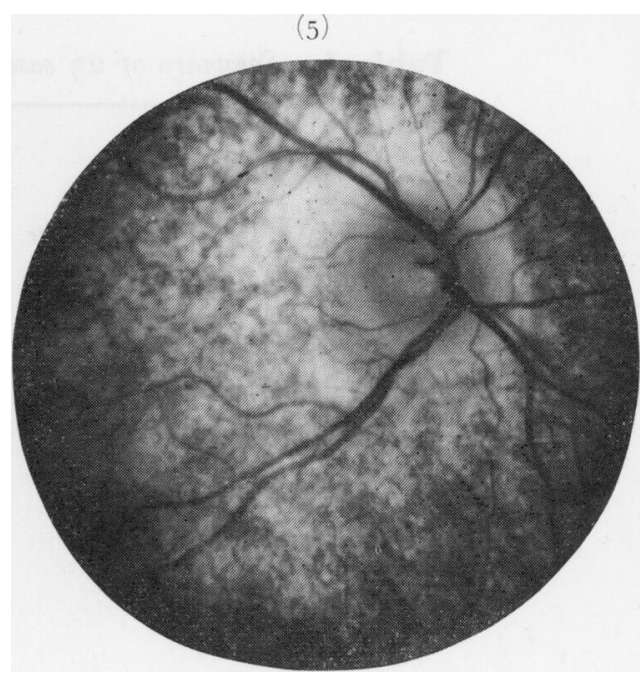

FIG. 4 Case 2. Facial view to show ptosis

FIG. 5 Case 2. Right disc and macula

Urine: No albumin or sugar present; amino acid chromatography showed normal pattern.

Radiology: Skull, chest, and hand $x$ rays normal.

Cerebrospinal fuid: initially blood-stained, subsequently clear and colourless, pressure normal; protein $216 \mathrm{mg}$./100 ml.; chloride $122 \mathrm{mEq} / \mathrm{l}$; cells: white blood cells $20 / \mathrm{c} . \mathrm{mm}$., red blood cells 48 I/c.mm.; Lange curve normal.

Electromyography: No abnormality detected in upper and lower limbs; ocular and facial muscles not examined.

Electroencephalograph : normal.

Tensilon test: negative.

Electrocardiograph: Right bundle branch block (Dr. Picton Thomas).

\section{PROGRESS}

The left ptosis was treated surgically by a fascia lata (bovine) frontalis sling procedure under general anaesthesia. In spite of the absence of Bell's phenomenon, the postoperative course was satisfactory with only minimal asymptomatic punctate corneal staining with fluorescein adjacent to the limbus inferiorly. The cosmetic result was initially excellent but the left ptosis appeared to have increased again after 4 months. Her condition remains otherwise unchanged.

\section{Discussion}

Since Davidson ( 1960 ) reviewed eighteen cases showing the association of external ophthalmoplegia and pigmentary degeneration of the retina, adding one case of his own, $2 \mathrm{I}$ further cases have been reported in the literature. These, as well as the two cases described in this paper, are summarized in Table I (overleaf). 
Table I Summary of 23 cases with chronic progressive external ophthalmoplegia and pigmenta

\begin{tabular}{|c|c|c|c|c|c|c|c|c|c|}
\hline \multirow{3}{*}{ Authors } & \multirow{3}{*}{ Date } & \multirow{3}{*}{$\begin{array}{l}\text { Case } \\
\text { No. }\end{array}$} & \multirow{3}{*}{ Sex } & \multicolumn{6}{|c|}{ Clinical features } \\
\hline & & & & \multirow{2}{*}{$\begin{array}{l}\text { Age at } \\
\text { onset }\end{array}$} & \multirow[b]{2}{*}{ Ptosis } & \multirow{2}{*}{$\begin{array}{l}\text { Ophthalmo- } \\
\text { plegia }\end{array}$} & \multirow{2}{*}{$\begin{array}{l}\text { Retinal } \\
\text { degener- } \\
\text { eration }\end{array}$} & \multicolumn{2}{|c|}{ Muscle weaknest } \\
\hline & & & & & & & & $\begin{array}{l}\text { Orbic- } \\
\text { ularis }\end{array}$ & Faci $\frac{\bar{c}}{\bar{\omega}}$ \\
\hline \multirow[t]{7}{*}{ Jampel and others } & 1961 & $\mathbf{I}$ & $\mathbf{M}$ & 48 & & + & + & & 间 \\
\hline & & 2 & $\mathbf{F}$ & & & + & + & & $\overrightarrow{0}$ \\
\hline & & 3 & $\mathbf{F}$ & Teens & & + & + & & $\overrightarrow{\vec{\omega}}$ \\
\hline & & 4 & $\mathbf{M}$ & Teens & & + & + & & 음 \\
\hline & & 5 & $\mathbf{F}$ & $\begin{array}{l}\text { Child- } \\
\text { hood }\end{array}$ & & + & + & & G \\
\hline & & 6 & $\mathbf{M}$ & Teens & & + & + & & ஸे \\
\hline & & 7 & $\mathbf{F}$ & $\begin{array}{l}\text { Child- } \\
\text { hood }\end{array}$ & & + & + & & 욱 \\
\hline Walton & $196 r$ & & $\mathbf{F}$ & $\begin{array}{l}\text { Child- } \\
\text { hood }\end{array}$ & + & + & + & & 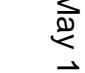 \\
\hline Harenko and Lappalainen & 1962 & & $\mathbf{F}$ & 24 & + & + & + & & $\overrightarrow{+}$ \\
\hline Stanworth & 1963 & & $\mathbf{M}$ & & + & & + & & $\varliminf_{\jmath}$ \\
\hline $\begin{array}{l}\text { Thomas, Cordier, Tridon, } \\
\text { and Saudax }\end{array}$ & 1963 & & $\mathbf{M}$ & 36 & + & + & + & & 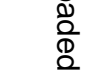 \\
\hline Guerci and Reny & 1964 & & $\mathbf{F}$ & 25 & + & + & + & & 응 \\
\hline Daroff and others & 1966 & & $\mathbf{F}$ & II & + & + & + & & $\stackrel{\text { to }}{=}$ \\
\hline \multirow[t]{2}{*}{ Malbrán } & 1966 & $\mathbf{I}$ & $\mathbf{M}$ & 7 & + & + & + & & \\
\hline & & 2 & $\mathbf{F}$ & 14 & + & & + & + & $+\stackrel{\dot{\phi}}{\circ}$ \\
\hline $\begin{array}{l}\text { Shy, Silberberg, Appel, } \\
\text { Mishkin, and Godfrey }\end{array}$ & 1967 & & $\mathbf{F}$ & 14 & + & + & + & & 잉 \\
\hline \multirow[t]{2}{*}{ Drachman } & 1968 & I & $\mathbf{F}$ & 8 & + & + & + & & \\
\hline & & 2 & $\mathbf{M}$ & 13 & + & + & + & + & \\
\hline \multirow[t]{3}{*}{ Rosenberg and others } & 1968 & $\mathbf{I}$ & $\mathbf{M}$ & 12 & + & + & + & + & $+\stackrel{N}{\omega}$ \\
\hline & & 2 & $\mathbf{M}$ & 12 & + & + & + & & $\sum_{0}^{0}$ \\
\hline & & 3 & $\mathbf{F}$ & 7 & + & + & + & & $+\stackrel{\complement}{\mathbb{D}}$ \\
\hline \multirow[t]{2}{*}{ Present cases } & 1970 & $\mathbf{I}$ & F & 10 & + & + & + & & 꿍 \\
\hline & & 2 & $\mathbf{F}$ & II & + & + & + & & $+\underset{\substack{\mathbb{D} \\
\mathbb{D}}}{\stackrel{\stackrel{P}{D}}{O}}$ \\
\hline
\end{tabular}


ation

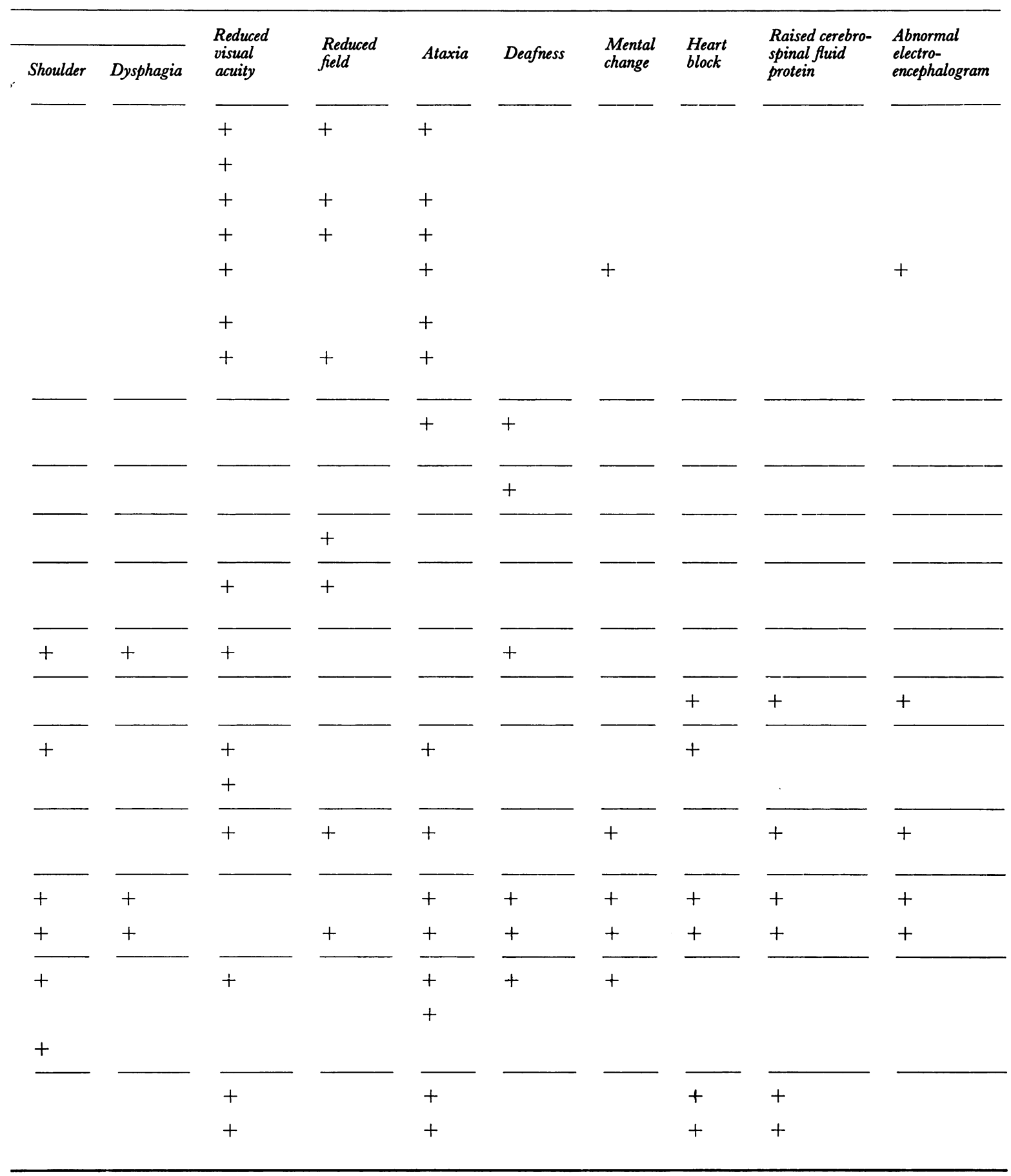


It is evident that the signs are not usually confined to the external ocular muscles and the retina. Involvement of the muscles of the face, neck, limbs, pharynx, and larynx, $\frac{\varrho}{7}$ ataxia, deafness, mental changes, heart block, raised protein content of the cerebrospinalo fluid, and electroencephalographic abnormalities are some of the changes common to many cases. This broad spectrum of associated signs appears to invalidate the concept of $\stackrel{0}{\rightarrow}$ Davidson (1960) of an homogenous group, which can be recognized as a syndrome. 등 Drachman (1968) entitled his paper "Ophthalmoplegia Plus" to emphasize the wide- $\frac{\overline{\bar{N}}}{\overline{\underline{D}}}$ spread neurodegenerative changes to be found in his four cases, two of which showed the association of external ophthalmoplegia and pigmentary degeneration of the retina. A comprehensive review of 28 cases of progressive ptosis and ophthalmoplegia by Rosenberg, Schotland, Lovelace, and Rowland (1968) included three with pigmentary degener- ation of the retina and again illustrated the variety of other signs which may be found in $\vec{\omega}$ such patients. The two cases reported in this paper also showed changes other than those involving the extraocular muscles and retina. Both had limb weakness, ataxia, heart block, and a raised cerebrospinal fluid protein content, and Case 2 also showed weakness $\mathrm{G}$ of the facial and neck muscles. Jampel, Okazaki, and Bernstein (196r) reported a Negro $\omega$ family in which seven members had ataxia and other neurological signs associated with $N$

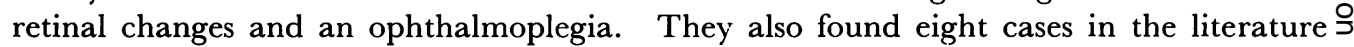
prior to 1960 , in which oculomotor palsies, retinal degeneration, and heredo-degenerative ataxia were combined in what they considered to be a single disease entity. In the family they described there were no cases of ptosis, unlike any of the others in Table I, and possibly $\vec{\varphi}$ these seven cases should not be included in that list. They are recorded, however, because they illustrate, together with the others, the diverse neurological associa tions which may be found in such patients.

It may become possible to classify these apparently heterogenous conditions into syndromes, if underlying defects, such as inborn errors of metabolism, are found to unify them.

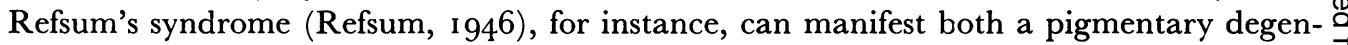
eration of the retina and a progressive external ophthalmoplegia (Daroff, I969) as well as $\overrightarrow{0}$ other neurological signs, and it appears to be caused by an abnormality of phytanic acid metabolism. Likewise the Bassen-Kornzweig syndrome (Bassen and Kornzweig, 1950), in which similar neurological signs can appear (Daroff, I969), may be due to a metabolic anomaly relating to the beta-lipoproteins. However, biochemical and haematological irregularities are not necessarily the direct cause of neurological anomalies. In the BassenKornzweig syndrome, for example, it is possible to speculate that the absence of beta- $\delta$ lipoprotein may affect the lipoid structure of the rods and cones; but it is equally likely that the genetic abnormality determining the absence of beta-lipoprotein in the blood may 음 be responsible also for the pigmentary degeneration of the retina (Wolff, Lloyd, and $\frac{7}{0}$ Tonks, 1964). In Refsum's syndrome, however, it has been shown by Eldjarn, Try, Stokke, Munthe-Kaas, Refsum, Steinberg, Avigan, and Mize (1966) that treatment with o a low phytanic acid diet will produce some clinical improvement, and this would suggest $N$ that, in this condition, the neurological signs are complications of the metabolic error $\underset{\omega}{N}$ rather than the direct manifestation of a genetic abnormality.

The fundus appearances in these cases do not conform to any pattern and the term "pigmentary degeneration of the retina" is sufficiently non-specific to be applied to all groups. In some patients typical tapeto-retinal bone-corpuscle pigmentation is described; in others the pigment is "granular" or "clumped" or "finely dusted". The distribution of these changes also varies: maximum pigmentary disturbance may be found at the posterior pole, at the equator, or in the periphery. The retinal arterioles may be attenuated, 
slightly narrowed, or normal. Optic atrophy is occasionally recorded and the visual fields may be affected, although they are usually intact.

The term "chronic progressive external ophthalmoplegia", which is used to denote a slowly progressing paralysis of the extraocular and levator palpebrae muscles, has been adopted in this paper because it is purely descriptive and does not involve any commitment as to aetiology. The terms "ocular myopathy" and "progressive nuclear ophthalmoplegia", the first indicating a primary disorder of muscle and the second a degenerative process involving the brain stem nuclei of the third, fourth, and sixth cranial nerves, are avoided because they do imply that the site, if not the cause, of the disease process is known. For over 50 years it was generally accepted that chronic progressive external ophthalmoplegia was the result of a degeneration of the brain stem nuclei, a theory first proposed by Möbius (I900). Kiloh and Nevin (I95I), however, reappraised the earlier myopathic theory (Fuchs, 1890) and this then became the accepted view for the next two decades. Recently the criteria involved in establishing a diagnosis of myopathy have been critically reassessed and doubt has been expressed regarding the aetiology in all cases of chronic progressive external ophthalmoplegia except those in which post mortem examination has demonstrated beyond doubt the site of the lesion (Walton, I96r; Daroff, Solitare, Pincus, and Glaser, I966; Rosenberg and others, I968; Daroff, I969).

The two investigations on which the myopathic theory largely relies are electromyography and biopsy of the extraocular muscles, but the interpretation of such data is usually equivocal so that a definitive diagnosis cannot be made on the basis of either (Rosenberg and others, 1968). The study of certain serum enzymes which are known to rise in muscular dystrophy, an established myopathic condition, has not received much attention in relation to chronic progressive external ophthalmoplegia and therefore the results of an investigation done by one of us (P.V.M.), in which the serum creatine phosphokinase levels were measured in eleven cases unassociated with pigmentary degeneration of the retina, are presented (Table II, overleaf). These cases were diagnosed according to the classification used by Liversedge ( 1963 ) and the serum creatine phosphokinase levels were measured by the method of Tanzer and Gilvarg (1959).

In the muscular dystrophies, especially of the Duchenne type, there is a marked rise in many serum enzymes, including creatine phosphokinase, aldolase, aspartate and alanine aminotransferases, and lactic dehydrogenase. The serum level of creatine phosphokinase, which is found almost exclusively in muscle, appears to be the most sensitive index for the diagnosis of muscle disease. The enzyme level may rise before the disease becomes clinically apparent and it can be used for the detection of clinically normal carriers of the abnormal gene causing muscular dystrophy (Hughes, I963; Pennington, 1969).

In the above series (Table II), only one case, in which the most prominent feature of the presumed myopathy was laryngo-pharyngeal weakness, showed a small elevation of the serum creatine phosphokinase. In Table I, of the 23 cases with chronic progressive external ophthalmoplegia and pigmentary degeneration of the retina listed, serum enzyme studies were reported in seven cases. Only in Case 2 reported in this paper was the serum creatine phosphokinase raised, though the elevation was considerable, the serum creatine phosphokinase being I 4 units $/ \mathrm{ml}$. compared with a normal range of $5^{-20}$ units $/ \mathrm{ml}$. Abnormal serum enzyme levels associated with progressive ophthalmoplegia have been recorded before. Magora and Zauberman (1969) found raised levels of serum creatine phosphokinase and aldolase in one patient of a series of six with progressive ophthalmoplegia, and Satoyoshi, Murakami, Kowa, Kinoshita, and Torii (1965) reported two patients who had a raised creatine phosphokinase level. Magora and Zauberman (1969) sug- 
Table II Serum creatine phosphokinase $(C P K)$ in chronic progressive external ophthalmoplegia unassociated with pigmentary degeneration of the retina (normal $<\mathrm{I} \cdot 5$ )

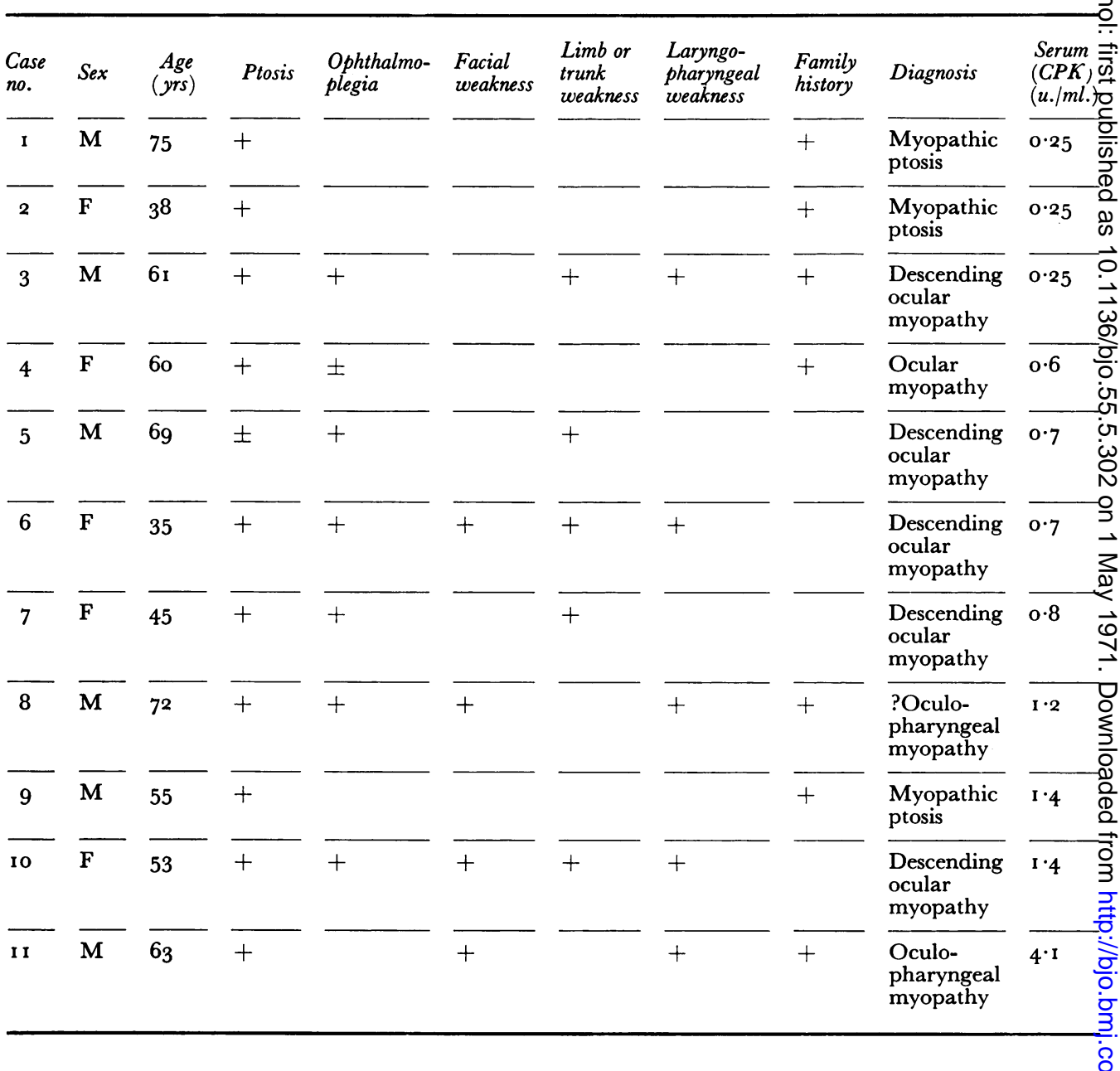

gested that enzyme levels were usually normal in patients with progressive ophthalmoplegia because of the small muscle bulk involved. All five cases with raised serum enzyme levels mentioned above had evidence of muscle disease outside the extraocular muscul $\frac{D}{0}$ ature, and this would tend to confirm the view that it is the bulk of muscle affected by disease which determines whether or not enzyme levels will rise.

The abnormal enzyme levels in cases of chronic progressive external ophthalmoplegia would appear to support the view that the disorder is myopathic in nature. It is known, $\omega$ however, that a modest rise in the serum level of creatine phosphokinase can occur in association with muscle denervation (Hughes, I963; Goto, Peters, and Reese, 1967) It is stated in the latter paper that "creatine phosphokinase elevation alone cannot always? distinguish between progressive muscular dystrophy and other neuromuscular disorders". Thus the detection of moderate rises in serum enzyme levels in cases of chronic progressive external ophthalmoplegia does not necessarily prove them to be myopathic, but a substantial rise, as in our Case 2, must provide strong support for a myopathic aetiology. 


\section{Summary}

Two cases of progressive external ophthalmoplegia associated with pigmentary degeneration of the retina are described and the relevant literature reviewed. The value of serum enzyme studies in the diagnosis of myopathy of the extraocular muscles is discussed and a study of serum creatine phosphokinase in eleven other cases of progressive external ophthalmoplegia is reported.

Mr. P. V. Mills wishes to thank Dr. G. K. McGowan, Consultant Chemical Pathologist, Bristol Royal Infirmary, for kindly arranging the serum creatine phosphokinase estimations listed in Table II.

\section{References}

BARNARD, R. I., and SCHOLz, R. O. (1944) Amer. F. Ophthal., 27, 621

BASSEN, F. A., and KORNZWEIG, A. L. (1950) Blood, 5, 381

DAROFF, R. B. (1969) Arch. Ophthal. (Chicago), 82, 845

DAROFF, R. B. SOlitARe, G. B., PINGuS, J. H., and GLASER, G. H. (1966) Neurology (Minneap.), 16, I6I DAvidson, s. I. (1960) Brit. F. Ophthal., 44, 590

DRAGHMAN, D. A. (1968) Arch. Neurol. (Chicago), 18, 654

ELdJARN, L., TRY, K., STOKKe, o., MUNTHE-KAAS, A. W., REFSUm, S., STEINBERG, D., AVigan, J., and MIZE, C. (I966) Lancet, $\mathbf{x}, 69$ I

FUchs, E. (1890) v. Graefes Arch. Ophthal., 36, Pt I, p. 234 (Quoted by Kiloh and Nevin, I95 I)

Goto, I., PETERS, H. A., and REESE, H. H. (1967) Arch. Neurol. (Chicago), r6, 529

GUERCI, O., and RENY, A. (1964) Bull. Soc. Ophtal. Fr., p. 82

harenko, A., and lappalainen, A. (1962) Nord. Med., 67, 24

hughes, B. P. (1963) Proc. roy. Soc. Med., 56, 179

JAMPEL, R. S., OKAZAKI, H., and Bernstein, H. (I96I) Arch. Ophthal. (Chicago), 66, 247

KILOH, L. G., and NEVIN, S. (I95I) Brain, 74, II5

LIVERSEDGe, L. A. (1963) Trans. ophthal. Soc. U.K., 83, 505

magora, A., and zauberman, H. (1969) Arch. Neurol. (Chicago), 20, I

MALBRÁN, E. s. (1966) Int. Ophthal. Clin., 6, 7 I I

мӧвıиs, Р. J. (1900) Cited by H. Wilbrand and A. Saenger, in "Die Neurologie des Auges", vol. I,

p. 130. Bergmann, Wiesbaden. (Quoted by Kiloh and Nevin, 1951)

PEnNington, R. J. (1969) In "Disorders of Voluntary Muscle", ed. J. N. Walton, 2nd ed., p. 392.

Churchill, London

REFSUM, s. (1946) Acta psychiat. neurol. (Kbh.), Suppl. $3^{8}$

Rosenberg, R. N., Schotland, D. L., LOVhlace, R. E., and RoWland, L. P. (1968) Arch. Neurol.

(Chicago), 19, 362

Satoyoshi, e., murakami, к., коWa, н., кinoshita, м., and toriI, J. (1965) Amer. F. Ophthal., 59, 668

SHY, G. M., SILBERBERG, D. H., APPEL, s. H., Mishkin, M. M., and Godfrey, e. H. (1967) Amer. F. Med., 42, 163

STANWORTH, A. (1963) Trans. ophthal. Soc. U.K., 83, 515

TANzer, M. L., and Gilvarg, c. (1959) F. Biol. Chem., 234, $320 \mathrm{I}$

thomas, C., CORDIER, J., TRIDON, P., and SAUdAX, E., (1963) Rev. Oto-neuro-ophtal., 35, 5

walton, J. N. (1960) In "Neuromuscular Disorders", Res. Publ. Ass. nerv. ment. Dis., 38, 388

WOlfF, O. H., Lloyd, J. K., and tonks, E. L. (1964) Exp. Eye Res., 3, 439 